$12-2018$

\title{
Film Review: El Vecino Alemán (The German Neighbor)
}

María L. Minassian

University of Buenos Aires, Law School

Follow this and additional works at: https://digitalcommons.usf.edu/gsp

\section{Recommended Citation}

Minassian, María L. (2018) "Film Review: El Vecino Alemán (The German Neighbor)," Genocide Studies and Prevention: An International Journal: Vol. 12: Iss. 3: 193-194.

DOI:

https://doi.org/10.5038/1911-9933.12.3.1637

Available at: https://digitalcommons.usf.edu/gsp/vol12/iss3/21

This Film Review is brought to you for free and open access by the Open Access Journals at Digital Commons @ University of South Florida. It has been accepted for inclusion in Genocide Studies and Prevention: An International Journal by an authorized editor of Digital Commons @ University of South Florida. For more information, please contact digitalcommons@usf.edu. 
Film Review: El Vecino Alemán (The German Neighbor)

\author{
María Luciana Minassian \\ Law School, University of Buenos Aires \\ Buenos Aires, Argentina
}

El vecino alemán (The German Neighbor)

Directors: Rosario Cervio, Martín Liji

Argentina, 2016

Reviewed by María Luciana Minassian

Law School, University of Buenos Aires

On May 20th, 1960, Adolf Eichmann was abducted by civilians and members of the Israeli Mossad secret service agents, from his house in the suburb of San Fernando, Province of Buenos Aires. The former lieutenant colonel was secretly living in Argentina, were he had entered ten years ago, with a fake passport issued by an Italian delegation of the International Committee of the Red Cross. Five days after the abduction he was in Israel, were he was prosecuted and charged under crimes against humanity, and later on May 31st, 1962, he was hanged.

El vecino alemán is a film about the life of Adolf Eichmann during the time he was hidden in Argentina, right after the Holocaust and Second War World II years. There are several references right from the start about the trial he faced in Israel at Jerusalem's courts, where he was convicted and executed for his criminal participation during the Nazi regime, on grounds that as a high command he was actively involved as a supervisor of the mass deportation of Jews to extermination camps in Nazi occupied eastern Europe during the war.

The trial itself shows different behaviors of Eichmann during it, who right from the beginning, keeps justifying every killing command and pictures himself as a humble server who was not able to change any single detail of the orders he was supposed to follow right from his superiors. There is no remorse in him, according to his own words, an absence of feelings, probably funded on the sense of loyalty that impregnated SS staff of the Nazi regime. The scenes on the trial, however, full of survivors testimonies, are a constant reminder of the harm Eichmann caused to entire civilian populations as a perpetrator, and a way to show the personal harm inflicted in each victim due to decisions he made and orders he gave.

The plot: back in Argentina, the film starts with actress Antonella Saldicco in the role of Renate Liebeskind, acting as a young Jewish translator, researcher and interviewer during the entire documentary. She starts her job with the interview of a grandson of four survivors from the Warsaw Ghetto, whom one of his grandmothers was also involved as a member of the Partisan resistance, and he explains the fight inside his mind on ways for acceptance of the suffering inheritance he received, and how to shape the family history to fit in his own life. There is some reference to a trip he had to do to Poland in order to deal with the historical facts that were presented to him by his grandparents. The need of a descendant to come to terms with sufferings he did not personally live but still the same will always be haunting his mind. There is also a group of young local people discussing about the fact that only perpetrators got punished while ordinary people who got involved, or where just by-standers got away with crime, they also mention the fact that Israel held Eichmann as a trophy, in exchange of the enormous amount of killed Jews.

References to Hannah Arendt will be present during the entire film, regarding the fact of her active involvement during Eichmann's trial, and her written essay about "Eichmann in Jerusalem". According to Arendt, evil does not originate out of hatred or perverse pleasure in inflicting pain or suffering. Evil is essentially banal, as it emerges out of the absence of the imaginative capacities that make the human and moral dimensions of our activities tangible.

Interviews on the film will continue with a testimony from a Jewish Argentine witness who attended the trial in Israel, and then an interview to Alvaro Abós, a lawyer who was stunned to learn that among Eichmann's last words there was an specific reference about his gratitude for Argentina, which triggered a research and later book called "Eichmann in Argentina". 
Since the perpetrator lived in different places in Argentina, Jewish translator Renate Liebeskind also visited the Province of Tucumán in order to get first hand testimonies of neighbors who knew him. They described them rather as a regular citizen or as a former boss, and also a very ordinary, educated, polite and serious person, who hardly spoke Spanish, and lived alone. Local researchers find out more witnesses who knew Eichmann as "Ricardo Klement" and worked at the "Capri" company. In Buenos Aires, he lived in the suburbs, in San Fernando, where testimonies of female neighbors recall the Israeli secret agents kidnapping Eichmann, who by the time was only known by the name "Ricardo Klement", and after the abduction they recalled the agents keeping him in his own house first, and later taking him to a plane dressed as a flight pilot, and drunk. One of them also remembers having followed the trial on tv streaming. Other female witness was an acquaintance of Eichmann's wife, and she remembers him as a good person, a polite customer who used to buy groceries at her store after his work day ended. There are huge contradictions between his life as a simple civilian in Buenos Aires and his former role during the Third Reich, where he neither prevented nor did he mind the tragic fate of hundreds of thousands, since by his own statement there was nothing he could do to avoid the deportation and killings procedure. Moreover, he denied the fact that deportees died inside the wagons during the trips to the KLs, but also did not take responsibility on these issues since they were not among his duties.

Paola Delbosco, a doctor in philosophy from La Sapienza University, explained the dehumanization process, not only for the perpetrators to find helpers in performing their tasks, but also installed among the victims, and the fact that this process also includes an active aggressive element, which makes the camp inmates do wrong to each other, after a period of mandatory starvation, dirtiness, and sleep deprivation. The loyalty element is also brought to the Eichmann trial, as a tool to comply with any orders given by the superiors. Doctor Delbosco also refers to Primo Levi's If This Is a Man Holocaust memoirs, to explain the dehumanization processes and how empathy is lost due to them.

Doctor Rafecas, an Argentine judge, presented documental testimonies were Eichmann's wife, denounced to a local judge his disappearance right after he was abducted by Israeli secret forces, and the reply from an Israeli Judge only confirmed the fact that there was nothing to be done in the case, so the judiciary requests from Argentina would not be able to bring him back to the country.

More neighbors from San Fernando, Buenos Aires were interviewed to find out that also Adolf Eichmann's sons did not speak about their father, nor his grandsons would say much, and the former house where he used to live was demolished because many people used to visit the place. He was still seen as a good neighbor who helped for improvements for the benefit of all neighbors...

Title of the Film: El vecino alemán (The German Neighbor); Directors: Rosario Cervio, Martín Liji; Producer: Martin Liji; Screenplay: Rosario Cervio, Martin Liji; Cinematography: Lucas Gaynor; Film Editor: Rosario Cervio; Sound Designer: Julian Caparros; Cast: Antonella Saldicco; Country: Argentina; Language: Spanish, German, Hebrew; Year of Production: 2016; Year of Release: 2018; Production Company: Nana Cine; Duration: 93 minutes. 